\title{
Mastigobasidium, a new teleomorphic genus for the perfect state of ballistosporous yeast Bensingtonia intermedia
}

\author{
Wladyslav I. Golubev \\ e-mail: wig@ibpm.serpukhov.su
}

All-Russian Collection of Microorganisms, Institute for Biochemistry and Physiology of Microorganisms, Russian Academy of Sciences, Pushchino 142292, Russia

\begin{abstract}
A new genus, Mastigobasidium, is proposed for teliospore-forming, xyloselacking, ballistosporogenous, glucuronate-positive yeasts. The distinguishing features of the genus are: germination of the teliospore by several long aseptate hyphae; curved phragmometabasidia development on the apices of these hyphae; and production of basidiospores on a peg in clusters. The type strain of heterothallic, nitrate-negative species Mastigobasidium intermedium is VKM Y-2720' (Bullera intermedia type strain) and the allotype strain is VKM Y-2727 ${ }^{\text {AL }}$ (Sporobolomyces weijmanii type strain).
\end{abstract}

Keywords: ballistosporous yeasts, teleomorph, Bensingtonia, Mastigobasidium

\section{INTRODUCTION}

In 1986, Nakase \& Suzuki described a species, Bullera intermedia, isolated from a dead leaf of Oryza sativa in Japan. They transferred that yeast to the genus Sporobolomyces Klyuver et van Niel because it lacks xylose in whole-cell hydrolysates (Nakase \& Suzuki, 1987). Another species, Sporobolomyces weijmanii Nakase et Suzuki, isolated from a dead leaf of Miscanthus sinensis was regarded by Yamada \& Nakagawa (1988) as being synonymous with Sporobolomyces intermedius (Nakase et Suzuki) Nakase et Suzuki, based on the electrophoretic comparison of seven enzymes. This was supported by nucleotide sequence analysis of the large subunit (LSU) rRNA, which showed that these two species have an identical sequence in the V3 region (Fell et al., 1992).

Contrary to species of Sporobolomyces which have Q10 , Sporobolomyces intermedius has Q-9 as its major ubiquinone component. The genus Bensingtonia Ingold is characterized among ballistospore-forming fungi by a Q-9 system and it lacks xylose. It was proposed to transfer Sporobolomyces species with Q-9 and lacking xylose to Bensingtonia (Nakase \& Boekhout, 1988).

During mating experiments with anamorphic basidiomycetous yeasts with the same mycocin sensitivity patterns, Golubev et al. (1996) observed the pro- duction of hyphae with clamp connections and spherical teliospores after mating of Bensingtonia intermedia (Nakase et Suzuki) Nakase et Boekhout and Sporobolomyces weijmanii type strains. After a rather prolonged rest period, the teliospores germinated to produce narrow and long hyphae which formed curved phragmometabasidia with lateral and terminal basidiospores on the apices. The features of basidial development displayed by this species are not present in any known teleomorphic genus of ballistosporous yeasts and, consequently, a new genus is proposed to accommodate the perfect state of Bensingtonia intermedia.

\section{METHODS}

Strains. All strains examined were from the All-Russian Collection of Microorganisms (VKM). The comparative studies included the type strains of Leucosporidium fellii Gimenez-Jurado et van Uden, Leucosporidium scottii Fell et al., Sporidiobolus ruineniae Holzschu et al., Bensingtonia yamatoana (Nakase et al.) Nakase et Boekhout, Sporobolomyces falcatus Nakase et al. and Sporobolomyces tsugae (Phaff et do Carmo-Sousa) Nakase et Itoh.

Morphological, physiological, biochemical and teleomorphic characteristics. The standard methods currently employed in yeast taxonomy (van der Walt \& Yarrow, 1984) were used. The methods for testing sensitivity to killer toxins and of analysis of monosaccharide composition of extracellular polysaccharides were described previously (Golubev, 1990). For electron microscopy, cells were harvested from cultures grown on malt agar at $20^{\circ} \mathrm{C}$ after $3 \mathrm{~d}$. The cells were fixed in $2 \%$ glutaraldehyde in a $0.05 \mathrm{M}$ cacodylate buffer $(\mathrm{pH} 7 \cdot 2)$, post-fixed in $2 \%$ osmium tetroxide and embedded in Epon 
812. Ultrathin sections were cut and stained with lead citrate solution.

\section{RESULTS}

\section{Latin diagnosis of Mastigobasidium Golubev gen. nov.}

Coloniae albidae aut cremeae. Cellulae ovales, per blastospores et ballistospores propagantes. Ultrastructura parties sicut in fermentis basidiomycetoides. Pseudomycelium et hyphae verae non-fibulatae incedere possunt. Hyphae secundum copulationem cellularum, cum septis nodosis et teliosporae. Teliosporae hyphis aseptatis gemmantia, metabasidia clavata, saepe curvata, septata in apicem hyphum formata; basidiosporae terminaliter et lateraliter, ellipsoidales vel bacillares, singulae vel aggregatae, sessiles vel in fulcris formantur, in germanatione blastosporas producentes. Urea finditur. D-Glucuronatum assimilantur. Fermentatio nulla. Ubiquinonum majus: Q-9. Xylosum in polysaccharides externis absens. Kalium nitricum non assimilantur. Species typica: Mastigobasidium intermedium Golubev.

\section{Description of Mastigobasidium Golubev gen. nov.}

Mastigobasidium (Mas.tig.o'bas.id.i.um. Gr. mastig whiplash or string; M.L. basidium basidium; Mastigobasidium development of basidia on the apices of thin, long hyphae).

Colonies are whitish to cream-coloured. Cells are oval, reproducing by budding and ballistospores. Cell wall ultrastructure is of the basidiomycetous type. Pseudomycelium and hyphae without clamp connections may be present. True mycelium with clamp connections and teliospores arises after conjugation of a compatible mating pair. The teliospore germinates to produce several long aseptate hyphae on the apices of which clavate, usually curved phragmometabasidia, develop. The basidiospores occurring laterally and terminally are ellipsoidal or bacilliform, single or in clusters, sessile or on pegs, and germinate by budding. Ureaseand D-glucuronate-positive. Fermentation absent. Major ubiquinone system: Q-9. Xylose is absent in extracellular polysaccharides. Nitrate is not assimilated. Type species: Mastigobasidium intermedium Golubev.

\section{Latin diagnosis of Mastigobasidium intermedium Golubev sp. nov.}

In aqua glucosum et extractum fermenti et peptonum continente, post dies 3 cellulae ovoidae et elongatae $(2.5-5 \cdot 1 \times 5 \cdot 1-17.0 \mu \mathrm{m})$. Post unum mensem sedimentum et pelliculae formantur. In agaro morphologico (Difco) post unum mensem cultura in striis glaucofusca, glabra aut crispulata, subnitida, mollis, margine glabra et undulatoque. Ballistosporae reniformes $(2 \cdot 5-5 \cdot 1$ $\times 5 \cdot 9-10 \cdot 2 \mu \mathrm{m})$. Pseudomycelium primitivum et mycelium verum non-fibulatum formantur. Fungus heterothallicus. Hyphae secundum copulationem cellularum, cum septis nodosis. Teliosporae intercalares aut terminales, fere sphaericaceae $(11.4-15.6 \times 11.4-21.3 \mu \mathrm{m})$, granulatae. Teliosporae hyphis gemmantia, metabasidia clavata curvata, bicellularis aut tetracellularis ex hyphis longa enata. Basidiosporae terminaliter et lateraliter, ellipsoidales vel bacillares $(2 \cdot 5-4 \cdot 2 \times 5 \cdot 1-9 \cdot 3 \mu \mathrm{m})$, singulae vel aggregata, sessiles vel in fibulis formantur, in germatione blastosporas producentes. Fermentatio nulla. Glucosum, galactosum (exigue), sucrosum (exigue), trehalosum (lente), cellobiosum (lente), arbutinum, glycerolum (lente), glucitolum, mannitolum, glucuronatum (lente), galacturonatum (lente), glucono- $\delta$ lactonum, 2-ketogluconatum, 5-ketogluconatum, lactatum (exigue), succinatum, citratum (exigue) et ethanolum assimilantur neque glucosaminum, ribosum, xylosum, $L$ - et D-arabinosum, rhamnosum, $\alpha$-methylglucosidum, salicinum, melibiosum, melezitosum, raffinosum, amylum, inulinum, erythritolum, ribitolum, arabitolum, xylitolum, galactitolum, inositolum et methanolum. Assimilatio L-sorbosi et maltosi variabilis. Ethylaminum, lysinum (exigue) et cadaverinum (exigue) assimilantur at non kalium nitricum, kalium nitrosum, creatinum nec creatininum. Urea finditur. Maxima temperatura crescentiae: $24^{\circ} \mathrm{C}$. Thiamin necessariae ad crescentiam. Materia amyloidea iodophila non formantur. Mannosum, glucosum et galactosum in polysaccharides externis demonstrable est. Ubiquinonum majus: Q-9. Proportio molaris guanini +cytosini in acido deoxyribonucleico: 58-62 mol\%. Typus VKM $\mathrm{Y}-2720^{\mathrm{T}}$ et allotypus VKM Y-2727 ${ }^{\mathrm{AL}}$ conservatur in collectione micro-organismorum Acad. Sci. Rossicum, Pushczino, Rossia.

\section{Description of Mastigobasidium intermedium Golubev sp. nov.}

Growth in glucose-yeast extract-peptone water: after $3 \mathrm{~d}$, the cells are oval or elongate [the width/length ratios are from 1.6-3.4 (mean 2.4)], 2.5-5.1 $\times$ 5.1-17.0 $\mu \mathrm{m}$ (mean $4.0 \times 8.5 \mu \mathrm{m}$ ) and after a month, there is a sediment and a pellicle. Growth on yeast morphology agar (Difco): after a month, the streak culture is yellowish grey, smooth to delicately wrinkled, dull, soft, and has an entire or undulating margin; ballistospores are kidney-shaped, 2.5-5.1 $\times$ 5.9-10.2 $\mu \mathrm{m}$ (mean $4.0 \times 7.6 \mu \mathrm{m}$ ), their width/length ratios are 1.3-2.5 (mean 1.9). Slide cultures on corn meal agar: after $10 \mathrm{~d}$, a primitive pseudomycelium and poor true mycelium without clamp connections are formed. The species is heterothallic. Conjugation of opposite mating types on corn meal agar results within 2 weeks in the formation of true mycelium with clamp connections at the septa and thick-walled, intercalary and terminal, usually spherical, ovoid or sometimes pear-shaped teliospores, 11.4 $15.6 \times 11.4-21.3 \mu \mathrm{m}$ (mean 13.8 $\times 15.0 \mu \mathrm{m})$. After soaking 3- to 4-week-old teliospores for 8-10 months at $5^{\circ} \mathrm{C}$ in distilled water they germinate by producing several (up to 10) narrow (width $1.4-2.5 \mu \mathrm{m}$ ) and long (from several tens to $200 \mu \mathrm{m}$ ) aseptate hyphae. Two- to four-celled club-shaped, usually curved phragmometa- 

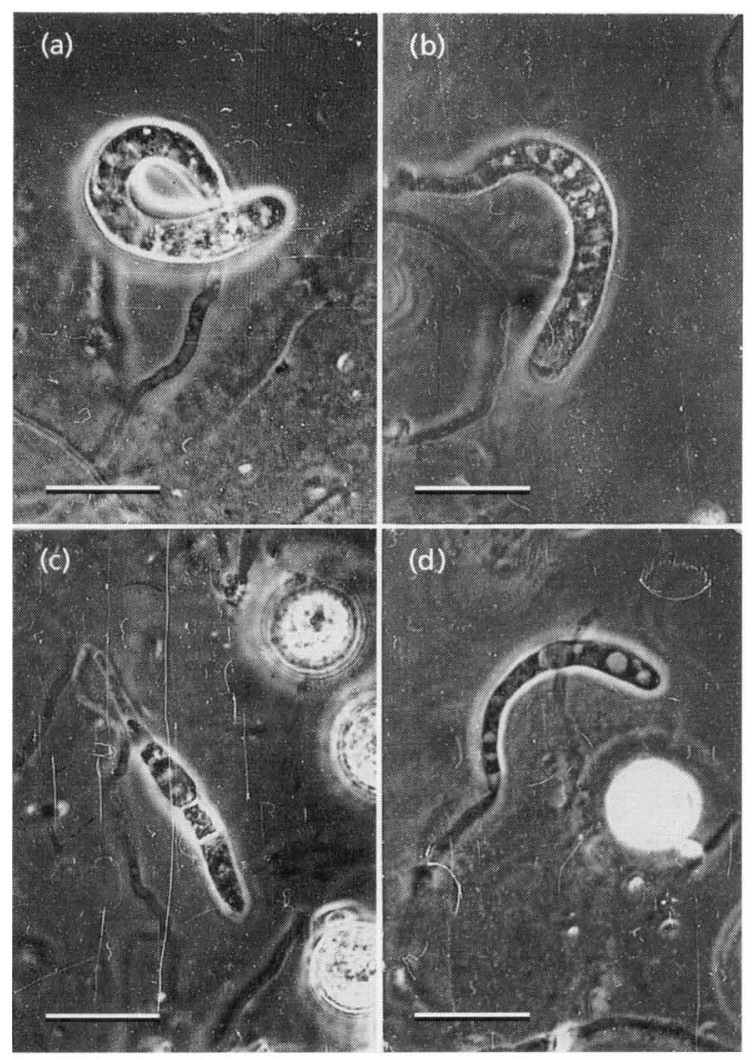

Fig. 1. Mastigobasidium intermedium VKM Y $-2720^{\top} \times$ VKM Y$2727^{\mathrm{AL}}$ grown on corn meal agar at $20^{\circ} \mathrm{C}$ for 4 weeks and then incubated in water at $5^{\circ} \mathrm{C}$ for 40 weeks. Phase-contrast. Bar, $20 \mu \mathrm{m}$. (a)-(d) Young metabasidia on hyphal tips.

basidia (Figs 1 and 2), which may break up into individual cells (Fig. 2c), are born on the apex of these hyphae. One to eight ellipsoidal or bacilliform basidiospores, $2.5-4.2 \times 5 \cdot 1-9.3 \mu \mathrm{m}$ (mean $3.5 \times 7.0 \mu \mathrm{m}$ ), are formed terminally and laterally (Fig. 2). They occur singly or in clusters of up to six in number on pegs (Fig. 2a) and germinate by budding (Fig. 2d). Fermentation: absent. Assimilation of carbon compounds: positive for D-glucose, arbutin, D-glucitol, D-mannitol, D-glucono- $\delta$-lactone, 2-keto-D-gluconate, 5-ketoD-gluconate, succinate and ethanol; weak for D-galactose, sucrose, DL-lactate and citrate; weak or negative for L-sorbose and maltose; negative for D-glucosamine, D-ribose, D-xylose, L-arabinose, D-arabinose, L-rhamnose, methyl $\alpha$-D-glucoside, salicin, melibiose, lactose, raffinose, melezitose, inulin, soluble starch, erythritol, ribitol, xylitol, L-arabitol, galactitol, i-inositol and methanol; slow for trehalose, cellobiose, glycerol, D-glucuronate and D-galacturonate. Assimilation of nitrogen compounds: negative for nitrate, nitrite, creatine and creatinine; weak for L-lysine and cadaverine; positive for ethylamine. Maximum temperature of growth (on malt agar): $24{ }^{\circ} \mathrm{C}$. Growth in vitamin-free medium: weak (thiamin is required for growth). Growth on $50 \%(\mathrm{w} / \mathrm{w})$ glucose-yeast extract agar: negative. Growth in the presence of $0.1 \%$
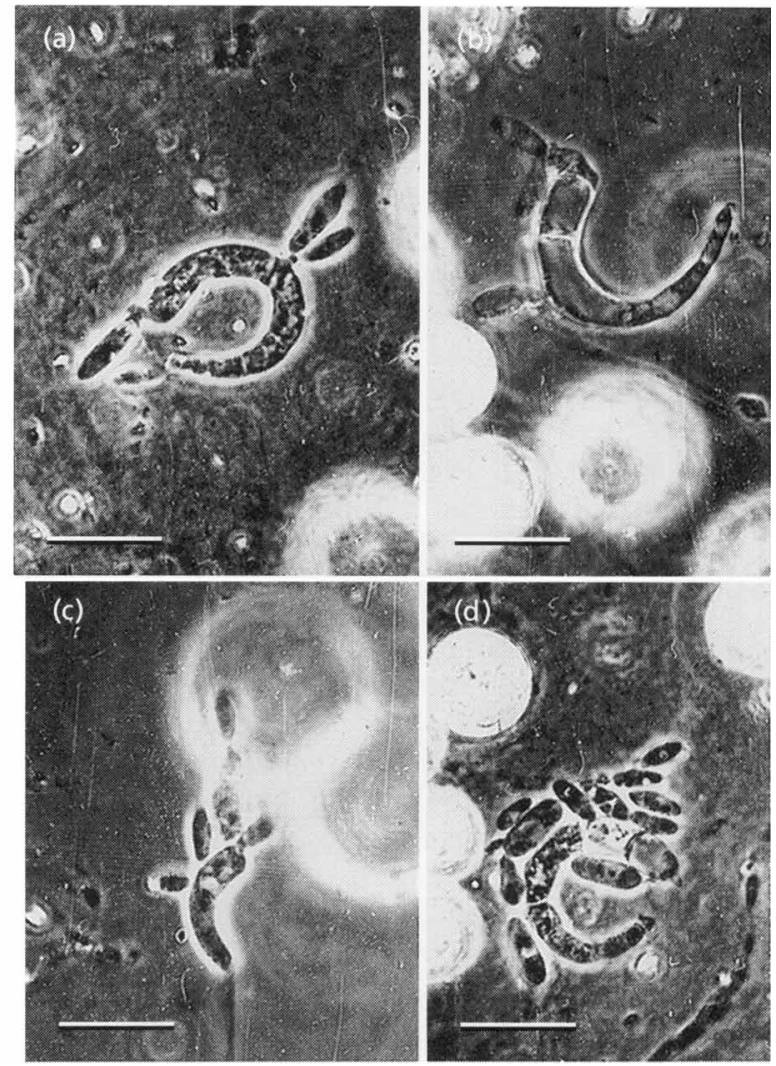

Fig. 2. Mastigobasidium intermedium VKM Y $-2720^{\top} \times$ VKM Y$2727^{\mathrm{AL}}$ grown on corn meal ager at $20^{\circ} \mathrm{C}$ for 4 weeks and then incubated in water at $5{ }^{\circ} \mathrm{C}$ for 40 weeks. Phase-contrast. Bar, $20 \mu \mathrm{m}$. (a)-(d) Phragmometabasidia and developing basidiospores.

cycloheximide: negative. Production of starch-like compounds: negative. Acid formation on chalk agar: negative. Urease activity: positive. Diazonium blue B reaction: positive. Sensitivity to mycocins: $M$. intermedium strains are weakly sensitive to the mycocins produced by Sporidiobolus salmonicolor, Rhodotorula glutinis and some killers of Rhodotorula mucilaginosa but are resistant to Sporidiobolus pararoseus and Rhodotorula pallida mycocins. They are insensitive to mycocins of tremellaceous (Bullera, Cystofilobasidium, Filobasidium, Cryptococcus) and ustilaginaceous (Tilletiopsis) yeast-like fungi (Golubev \& Boekhout, 1995; W. I. Golubev, unpublished data). Cell wall structure by TEM: sections showed the cell wall to be of the basidiomycetous type. Monosaccharide composition of extracellular polysaccharides: mannose, glucose and galactose (at molar ratios of $1: 0 \cdot 4: 0 \cdot 3$ ); fucose occurs in trace amounts. $\mathrm{G}+\mathrm{C}$ content: $57 \cdot 8,60 \cdot 0$, 60.3 and $62.5 \mathrm{~mol} \%$ (from $T_{\mathrm{m}}$ ) and $58.9 \mathrm{~mol} \%$ (by HPLC) (Nakase \& Suzuki, 1986, 1987; Boekhout, 1991; Takashima et al., 1995a). The levels of DNA similarities of Mastigobasidium intermedium to species of Bensingtonia are 7-14\% (Takashima et al., 1995b). Major ubiquinone: Q-9 (minor fractions Q-8, Q-10) (Nakase \& Suzuki, 1987). Type strain: VKM Y $-2720^{T}$ 
$\left(=\mathrm{JCM} 5291^{\mathrm{T}}=\mathrm{CBS} 7226^{\mathrm{T}}=\mathrm{IFO} 10178^{\mathrm{T}}=\mathrm{NRRL}\right.$ Y-17315 $)$. Allotype strain: VKM Y-2727 ${ }^{\mathrm{AL}}$ (= JCM $5651^{\mathrm{AL}}=\mathrm{CBS} 7241^{\mathrm{AL}}=7281^{\mathrm{AL}}$ ). They have been isolated from the dead leaves of Oryza sativa and Miscanthus sinensis in Japan and deposited in the collection of yeasts of the All-Russian Collection of Microorganisms, Institute for Biochemistry and Physiology of Microorganisms, Russian Academy of Sciences, Pushchino, Russia. Anamorph: Bensingtonia intermedia (Nakase et Suzuki 1986) Nakase et Boekhout 1988. Synonyms: Bullera intermedia Nakase et Suzuki 1986; Sporobolomyces intermedius (Nakase et Suzuki 1986) Nakase et Suzuki 1987; Sporobolomyces weijmanii Nakase et Suzuki 1987.

\section{DISCUSSION}

The teliospore-forming yeasts include organisms both of tremellaceous (Cystofilobasidium, Mrakia, Sterigmatosporidium) and sporidiobolaceous affinity (Kondoa, Leucosporidium, Rhodosporidium, Sakaguchia, Sporidiobolus). The absence of xylose in the extracellular polysaccharides and its sensitivity to mycocins of sporidiobolaceous but not of tremellaceous killers place Mastigobasidium intermedium in the group of genera of sporidiobolaceous affinity. Sporidiobolus Nyland is the only genus in this group characterized by the ability to produce ballistospores. Moreover, in some species of this genus the metabasidia are born on a stalk that is $3-26 \mu \mathrm{m}$ in length. Sporidiobolus species, however, are deeply pigmented, glucuronate-negative, Q-10-equipped and rather distant from Mastigobasidium intermedium according to rRNA comparisons (Nakase et al., 1993; Fell et al., 1995). In these characteristics, Mastigobasidium is more similar to the non-ballistospore-forming genus Leucosporidium Fell et al., especially to the species $L$. fellii Gimenez-Jurado et van Uden that produces clusters of bacilliform basidiospores. From my observations, a connecting short stalk is present sometimes in the straight phragmometabasidium of $L$. fellii, but Mastigobasidium clearly differs from both these genera (and from all other known sporidiobolaceous teleomorphs) in the formation of several curved phragmometabasidia on the apices of long hyphae (basidiophores) derived from one germinated teliospore. The pigmentation of the colonies, ballistospore formation, testing for assimilation of glucuronate and nitrate are most useful in the routine identification of these genera.

In most cases, rDNA sequence comparisons place Mastigobasidium intermedium within the Sporidiales although its intra-order position varies depending on the number and sets of taxa studied, the type of rRNA and methods for inferring phylograms. Among teleomorphic yeasts, this species was closely related to $L$. scottii from the analysis of small subunit (SSU) rDNA sequences predominantly of Bensingtonia spp. (Takashima et al., 1995a, b). However, from a study based on partial sequences of SSU rRNA from mainly ballistosporous yeasts, Mastigobasidium intermedium was located on a branch which was rather far from $L$. scottii (Nakase et al., 1993). On the other hand, the analysis based on partial sequences of LSU of rDNA from 148 heterobasidiomycetous species showed that Mastigobasidium intermedium clustered with $L$. fellii and L. scottii (Fell et al., 1995). A close relationship between Leucosporidium and Mastigobasidium is in conflict with a phylogenetic analysis using SSU rRNA gene sequences from both yeasts and mycelial basidiomycetes (Swann \& Taylor, 1995). In this study Mastigobasidium intermedium, together with Kondoa malvinella, was placed in the Agaricostilbum clade distant from the Sporidiales clade (Leucosporidium, Rhodosporidium and Sporidiobolus) in the class Uredinomycetes. As is evident from this, the phylogenetic position of Mastigobasidium intermedium among the teliosporic xylose-lacking yeasts is still unclear.

Mastigobasidium intermedium is the first perfect state found in species of Bensingtonia which occur scattered on several branches of the phylogenetic trees based on rRNA sequences (Fell et al., 1995; Takashima et al., $1995 \mathrm{a}, \mathrm{b}$ ), and it is unlikely that their teleomorphs will be classified in the genus described. According to sequence data the anamorphic species Sporobolomyces falcatus and Sporobolomyces tsugae were closely related to Mastigobasidium intermedium (Nakase et al., 1993).

The work was supported by the Russian national scientific project 'Biological diversity'.

Boekhout, T. (1991). A revision of ballistoconidia-forming yeasts and fungi. Stud Mycol 33, 1-194.

Fell, J. W., Statzell-Tallman, A. \& Lutz, M. J. (1992). Partial rRNA sequences in marine yeasts: a model for identification of marine eukaryotes. Mol Marine Biol Biotechnol 1, 175-186.

Fell, J. W., Boekhout, T. \& Freshwater, D. W. (1995). The role of nucleotide analysis in the systematics of the yeast genera Cryptococcus and Rhodotorula. Stud Mycol 38, 129-146.

Golubev, W. I. (1990). Killing pattern of Cystofilobasidium bisporidii mycocin from taxonomic viewpoint. Mykol Phytopathol 24, 542-547 (in Russian).

Golubev, W. I. \& Boekhout, T. (1995). Sensitivity to killer toxins as a taxonomic tool among heterobasidiomycetous yeasts. Stud Mycol 38, 47--58.

Golubev, W. I., Churkina, L. G. \& Seregina, S. A. (1996). Intergeneric action spectra of the Rhodotorula mucilaginosa mycocins. Izv Ross Akad Nauk Ser Biol 5, 523-529 (in Russian).

Nakase, T. \& Boekhout, T. (1988). Emendation of the genus Bensingtonia Ingold. J Gen Appl Microbiol 34, 433-437.

Nakase, T. \& Suzuki, M. (1986). Bullera intermedia sp. nov. and Sporobolomyces oryzicola sp. nov. isolated from dead leaves of Oryza sativa. J Gen Appl Microbiol 32, 149-155.

Nakase, T. \& Suzuki, T. (1987). Studies on ballistospore-forming yeasts from the dead leaves of Miscanthus sinensis with description of the new species Sporobolomyces miscanthi, Sporobolomyces subroseus and Sporobolomyces weijmanii. J Gen Appl Microbiol 33, 177-196. 
Nakase, T., Takematsu, A. \& Yamada, Y. (1993). Molecular approaches to the taxonomy of ballistosporous yeasts based on the analysis of the partial nucleotide sequences of $18 \mathrm{~S}$ ribosomal ribonucleic acids. J Gen Appl Microbiol 39, 107-134.

Swann, E. C. \& Taylor, J. W. (1995). Toward a phylogenetic systematics of the Basidiomycota: integrating yeasts and filamentous basidiomycetes using $18 \mathrm{~S}$ rRNA gene sequences. Stud Mycol 38, 147-161.

Takashima, M., Suh, S.-O. \& Nakase, T. (1995a). Phylogenetic relationships among species of the genus Bensingtonia and related taxa based on small subunit ribosomal DNA sequences. $J$ Gen Appl Microbiol 41, 131-141.
Takashima, M., Suh, S.-O. \& Nakase, T. (1995b). Bensingtonia musae sp. nov. isolated from a dead leaf of Musa paradisiaca and its phylogenetic relationship among basidiomycetous yeasts. J Gen Appl Microbiol 41, 143-151.

van der Walt, J.P. \& Yarrow, D. (1984). Methods for the isolation, maintenance, classification and identification of yeasts. In The Yeasts: a Taxonomic Study, 3rd edn, pp. 45-104. Edited by N. J. W. Kreger-van Rij. Amsterdam: Elsevier.

Yamada, Y. \& Nakagawa, Y. (1988). An electrophoretic comparison of enzymes in strains of the Q9-equipped species in the genus Sporobolomyces Kluyver et van Niel (Sporobolomycetaceae). J Gen Appl Microbiol 34, 289-295. 